\title{
SZÖVETTEKERCSELŐ EGYSÉG TERVEZÉSE
}

\section{DESIGN OF A FABRIC WINDING UP UNIT}

\author{
Márton László1, Szigeti Ferenc, ${ }^{2}$ Gergely Dezső ${ }^{3}$ \\ Nyíregyházi Egyetem, Müszaki és Agrártudományi Intézet, Müszaki Alapozó, Fizika és Gépgyártástechno- \\ lógia Tanszék. Nyíregyháza, Magyarország \\ 1 lacuko97@gmail.com \\ ${ }^{2}$ szigeti.ferenc@nye.hu \\ ${ }^{3}$ dezso.gergely@nye.hu
}

\begin{abstract}
For air-spring production the fabric winding is what prepares the semi-finished materials. The rubber body, that we called the membrane is made from using several layers of fabric and rubber. Building together these layers defines the mechanical properties. During the winding up, we prepare the cut rubber or fabric layers in rolls. Quality of rolling and the performance to make the semi-finished material, depend on the machine which is used for the winding. To satisfy the higher production capacity it was necessary to create a modern construction using automated systems. To assure the ergonomic expectations was a main viewpoint too. My thesis main goal is to explain, in detail, my design and to prove the device structural solutions using finite element analysis.
\end{abstract}

Keywords: air-spring production, fabric winding, automated systems, finite element test, tool designing.

\section{Összefoglalás}

A szövettekercselés a légrugógyártás folyamatára készíti elő a félkész anyagot. A légrugók gumieleme több gumirétegből épül fel, melyek megfelelő egymásra építése az előírt rétegrendben határozza meg a vulkanizálást követő mechanikai tulajdonságokat. A szövettekercselés során a vágott gumielemet készítjük elő tekercsekben. A tekercselés minősége és teljesítménye alapvetően befolyásolja a gyártás kapacitását. A megnövekedett gyártási igények kielégítése érdekében szükséges volt egy korszerü, automatizált rendszerrel ellátott szövettekercselő egység kialakítására, amely ugyanakkor lehetővé teszi az ergonómiai feltételek javítását is. A dolgozatom célja ennek a berendezésnek a részletes megtervezése, valamint véges elemes szimulációkkal a szerkezeti megoldások ellenőrzése.

Kulcsszavak: légrugógyártás, szövettekercselés, automatizált rendszer, végeselemes szimuláció, készüléktervezés.

\section{Bevezető}

Az egyetemi tanulmányaimat a duális képzés keretében folytattam a nyíregyházi Continental ContiTech Magyarország Kft.-nél. A gyakorlati időm alatt megismerkedtem a közlekedési és ipari termékek gyártására fókuszáló gumiipari termékek gyártási folyamataival, illetve azok gyakorlati felhasználásával [1].

Az üzemben jelenleg alkalmazott szövettekercselő egység elavult, a tekercsek minősége a mai követelményeknek már nem felel meg, ezért üzemi feladatként megbízást kaptam egy új szövettekercselő egység kifejlesztésére.

Elsőként bemutatom a légrugógyártáshoz szükséges folyamatokat, meghatározom a szövettekercselő egység gyártási folyamatban történő elhelyezkedését. Ezt követően a fejlesztés során alkalmazott szerkezeti megoldások magyarázata következik. A váz, a kiegészítő berendezések és segédrendszerek szerepét, funkcióját, illetve a keletkező terhelésekkel szembeni ellenállását 
vizsgálom. A fejlesztés célja az elavult szerkezet korszerüsítése, a növekvő vevői igények, illetve a cég által megadott szempontok figyelembevételével. A szerkezeti megoldások kidolgozása után elkészítettem a gyártáshoz szükséges műszaki dokumentációt.

\section{A korábban alkalmazott szövetteker- cselő egység bemutatása}

A folyamat elején a kalanderezett tekercset a gépbe helyezik, melynek szövetelemeit még előzőleg a felhasználási területnek megfelelően szögbe és méretre vágják. Ez a megmunkált gumilap hevederen érkezik az operátorhoz, akinek a feladata a vágott szövet egyesítése (végtelenítése). A dolgozó átlapolással egymásra helyezi a lapokat, melyeket a szögben elhelyezett heveder a tekercselőegységhez szállítja (1. ábra). A végtelenített lapokat itt egy ún. kísérőszövetbe tekerik, mely elválasztórétegként funkcionálva meggátolja a gumifilm, valamint a szintén itt készülő szövetre felpréselt gumifilm összetapadását. Így készülnek el a felhasználásra kész tekercsek. A tekercselőegység működésétől függ a termelés kapacitása, a tekercsek minősége (gumilapok, szövetlapok gyűrődése nem megengedett!).

\section{A korábban alkalmazott berendezés jellemző hibái}

Az első hiba a tekercselésben a gép csapágyazásából ered. A tekercs tengelye két oldalról van csapágyazva. A tengelyt ki- és be kell helyezni a tekercselés végén és annak kezdetén. Erre a célra egy olyan tengelycsatlakozás van kialakítva, melyben egy pneumatikus munkahenger villás

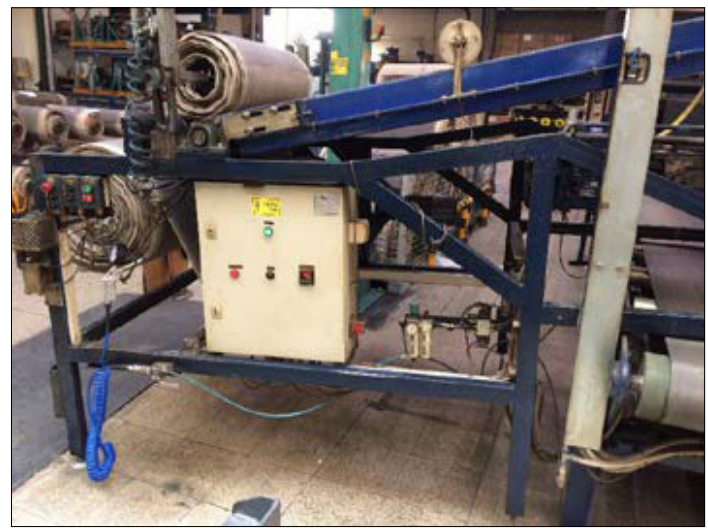

1. ábra. Régi szövettekercselő egység vége egy ellenrugóval biztosított nyitófüles reteszt old ki (2. ábra).

E megoldásnak köszönhetően a tekercsek tengelyének ki- és behelyezése egyszerű, viszont a tengelynek szabad játéka van a csatlakozókban, melynek következtében a tekercselés nem lesz megfelelő minőségű. A tengelyirányú holtjáték következtében megszűnik az egytengelyűség és a tekercsben található szövet gyűrődött lesz, vagy esetenként a szövetlapok elcsúsznak egymáshoz képest, ill. szétválnak.

A tekercselés folyamán, ahogy növekszik a feltekercselt anyag, úgy a tekercs átmérője is növekszik, ezért biztosítani kell a csapágyház és a csatlakozás lineáris elmozdulását. Ennek megoldására egy úgynevezett hornyos oszlop található. Maguk a csatlakozó tengelyvégek 2 darab egysorú mélyhornyú golyóscsapágy segítségével a nekik megfelelően kialakított hornyokban (3. ábra) képesek elvégezni a lineáris mozgást. Az üzemi tapasztalatok szerint a csapágyak a hornyokban gyakran megragadtak, ami a tekercsben kárt okozott.

Problémát jelentett a kész tekercs ki- és behelyezése is. A feltekercselt szövet súlya esetenként meghaladja az 50 kg-ot, az érvényes munkavédelmi szabályok szerint ezt a súlyt már emberi erővel nem szabad mozgatni. Erre a célra a gép mellett található egy daru, mely a tekercs kivételére szolgál. A daru használatával a tekercs már kivehető a gépből, azonban a daru emelőkarjának a tekercshez való pozicionálása, biztonságos beállítása nehézkes és időigényes folyamat

$\mathrm{Az}$ ismertetett hibajelenségek, illetve a jelenlegi egység gyakori karbantartási igénye miatt felmerült a szükségessége egy új szerkezet, illetve konstrukció kidolgozásának, mely korszerűbb és megbízhatóbban müködik.

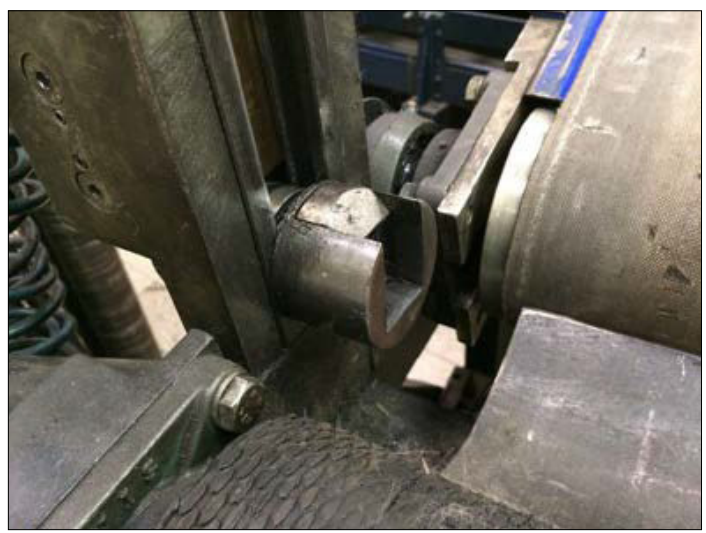

2. ábra. Tengelycsatlakozás a géphez 


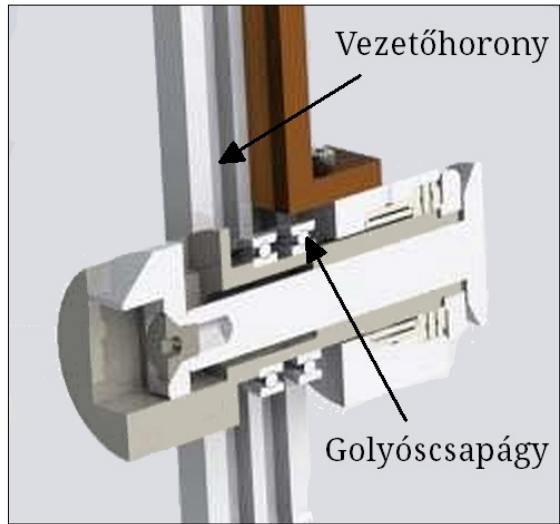

3. ábra. Tekercselőoszlop metszete

\section{Fejlesztési javaslatok a tekercselő- egység korszerüsítésre}

A feladat megfogalmazását követően két különböző működési elvű konstrukció tervét készítettem el. Mindkét verzió a legfontosabb követelmények szem előtt tartásával készült el, azonban szerkezeti megoldásaik, illetve működésük is jelentősen eltér egymástól.

\subsection{Billenőkaros változat}

Az első változat, a „Billenőkaros tekercselő berendezés” (4. ábra) kiemelendő előnye, hogy a szerkezete egyszerü, ugyanakkor működtetése automatizált.

Müködése: A folyamat indításakor az operátor az üres tekercsdobot a tengellyel együtt behelyezi a gép karjaiban található csatlakozóelemekbe, melyet a gép villamos motorok segítségével a tekercsasztal hevederére helyez. A tekercsek kialakítását a heveder biztosítja, az átmérőkülönbség kiküszöbölését a szabadon mozgó karok teszik lehetővé. A tekercselési folyamat végeztével a szerkezet kiemeli az asztalról az elkészült tekercset, melyet a berendezés az operátor munkaszintjére szállít, majd a folyamat ismétli önmagát.

\subsection{Oszlopos tekercselőegység}

A második fejlesztési változat az ún. „Oszlopos szövettekercselő egység” (5. ábra). Főbb jellemzői: magasfokú automatizáltság, ergonómiai szempontoknak való teljes körű megfelelőség. A szerkezet kialakítása komplex, az egyedileg gyártott alkatrészek kialakítása bonyolult, azonban CNC-vezérlésű megmunkáló berendezéseken a megmunkálás megvalósítható. Jelentős előnyt jelent, hogy az alkatrészek 80\%-a a kereskedelmi forgalomban beszerezhető, így meghibásodás esetén a javítás gyorsan elvégezhető.

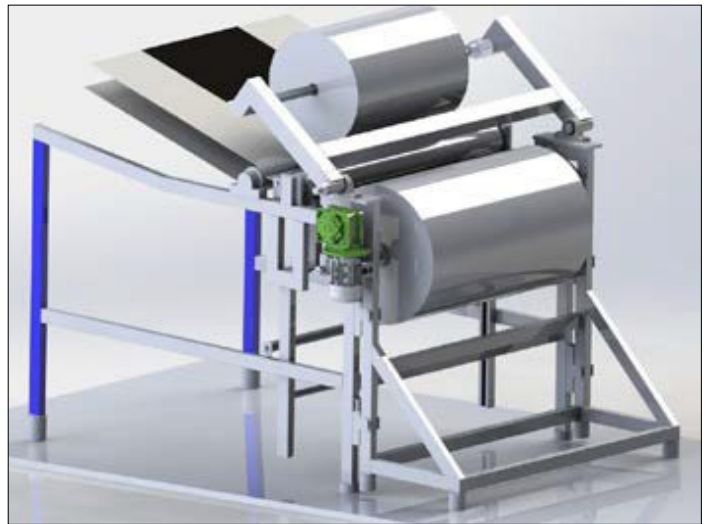

4. ábra. Billenőkaros tekercselőegység

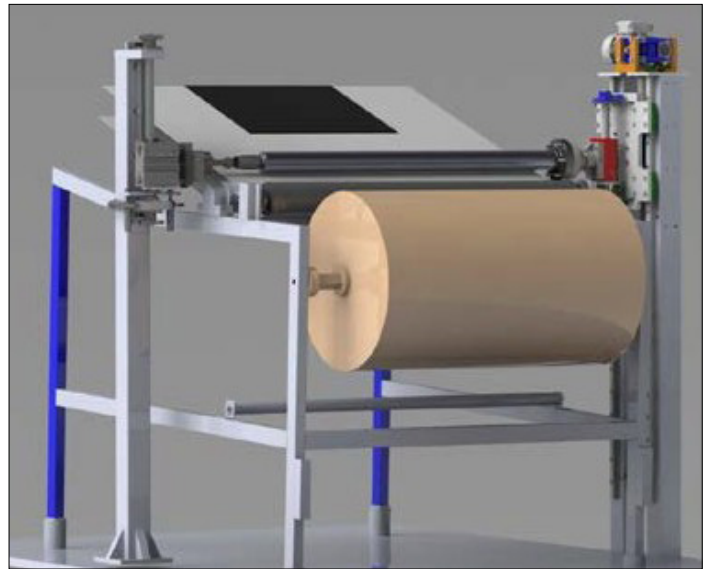

5. ábra. Oszlopos szövettekercselő egység

\subsection{Választott konstrukció}

A két változat elvi kidolgozását követően üzemi megbeszélést indítottunk, amelyen a berendezéssel dolgozó operátorokkal, illetve üzemvezetőkkel együtt kiválasztottuk a cég számára legmegfelelőbb megoldást.

Az oszlopos tekercselőegységet (6. ábra) tartottuk minden szempontból a számunkra legmegfelelőbbnek. Így következhetett a szerkezet komplex kidolgozása.

\section{Az oszlopos szövettekercselő egység föbb jellemzői}

Alapvetően a berendezés két fő egységre különíthető el. A következőkben a fő részeket bal oldali felépítményként és jobb oldali felépítményként mutatom be. Ezek összehangolt működtetése biztosítja a félkész anyag gyártásához szükséges működési feltételeket. 


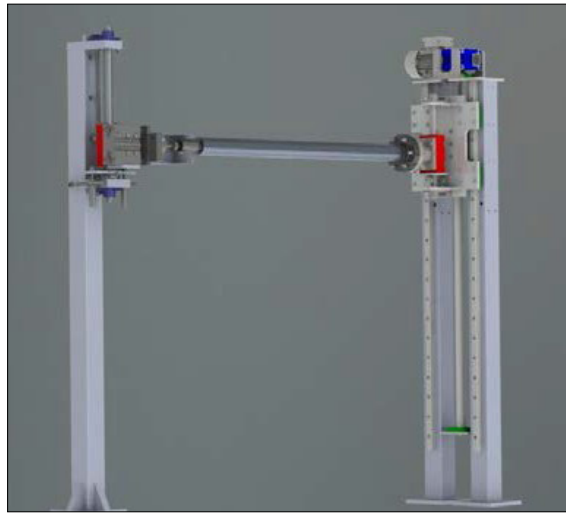

6.ábra. Az oszlopos szövettekercselö egység váz-szerkezete

\subsection{Bal oldali felépítmény}

A berendezés ezen részének elsődleges feladata a pneumatikus megfogótengely központosítása, továbbá a párhuzamosság biztosítása a hevederasztallal. Ezeket a funkciókat a 7. ábrán látható elemek biztosítják.

Működése: Egy pneumatikus munkahenger csapágyazással ellátott forgo, központosító kúpot nyit és zár. Ez a megoldás biztosítja a megfogó tengely központosítását. Szükség volt az átmérőkülönbség növekedéséből adódó méretkülönbség kompenzálására, melyet egy függőleges irányú elmozdulást végző lineáris tengely, illetve csapágyház biztosít. A pneumatikus munkahenger alatt található két csillapító munkahenger, melyek feladata a tekercselés végeztével a kúp oldását követő visszacsúszás csillapítása, illetve e berendezés alaphelyzetbe történő állítása. A lineáris tengelyek a tengelyre merőleges irányú állíthatósággal rendelkeznek, mely a beszerelést teszi egyszerüvé, illetve lehetővé teszik a vázszerkezet elhelyezéséből adódó nehézségek kiküszöbölését.

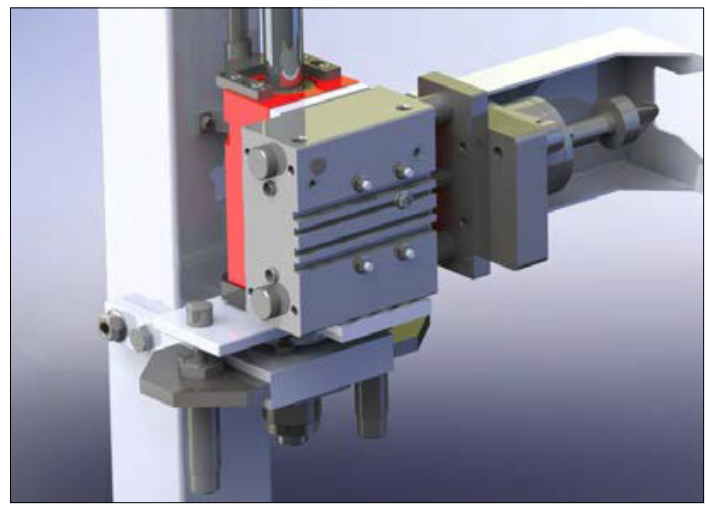

7. ábra. Bal oldali felépítmény fóbb szerelvényei

\subsection{Jobb oldali felépítmény}

A jobb oldali felépítmény a tekercselő egység (8. ábra) legkomplexebb egysége. Feladata a tekercselés optimalizálása, a keletkező terhelések felvétele, a kész tekercs mozgatása. Az elkészült tekercs súlyát (átlagosan $50 \mathrm{~kg}$ ) és a segédberendezések összeadódó tömegét a szerkezetnek alakváltozás nélkül kell viselnie, illetve mozgatnia.

A felépítménnyel szemben 3 fő követelményt támasztunk: a folyamatos és jó minőségű tekercsek kialakítása, a félkész anyag biztonságos mozgatása, valamint hogy mindezeket a feladatokat a felépítmény automatizált rendszerrel hajtsa végre. $\mathrm{Az}$ oszlopszerkezeten található 1-1 sínpár, amelyen a segédberendezést tartó lapra erősített lineáris kocsik biztosítják a függőleges mozgást. Az oszlopok között egy trapézmenetes orsó van elhelyezve, melyet a szerkezet tetején található villanymotor hajt meg a szükséges irányban. A tartólapon egy lineáris tengely [2] található, amely már az előzőekben részletezett átmérőkülönbség kompenzálását szolgálja. Az operátornak a tekercselés végén kézzel kell kinyitnia (biztosítási funkció) az egységet. Erre a célra a lineáris csapágyház alatt egy forgótárcsa került elhelyezésre, amely lehetővé teszi a könnyü nyitást, illetve zárást.

A 9. ábrán bemutatott metszeten láthatók a szerkezet főbb elemei. Az ábra bal oldalán talál-

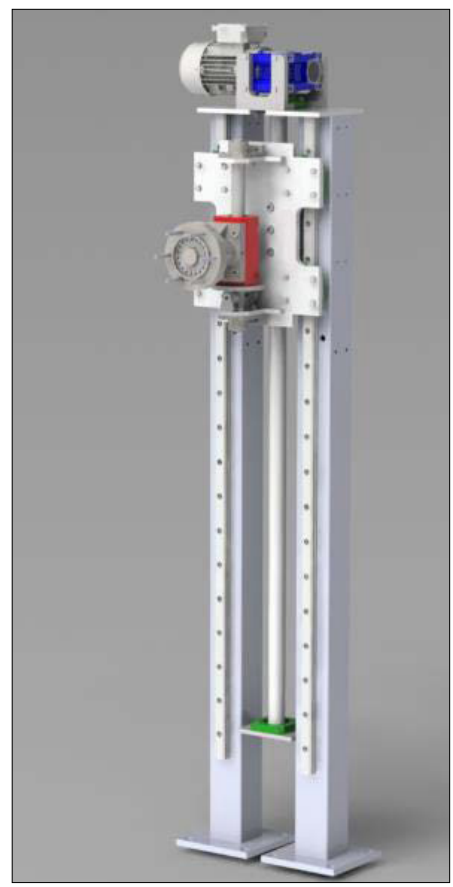

8. ábra. Jobb oldali felépítmény 


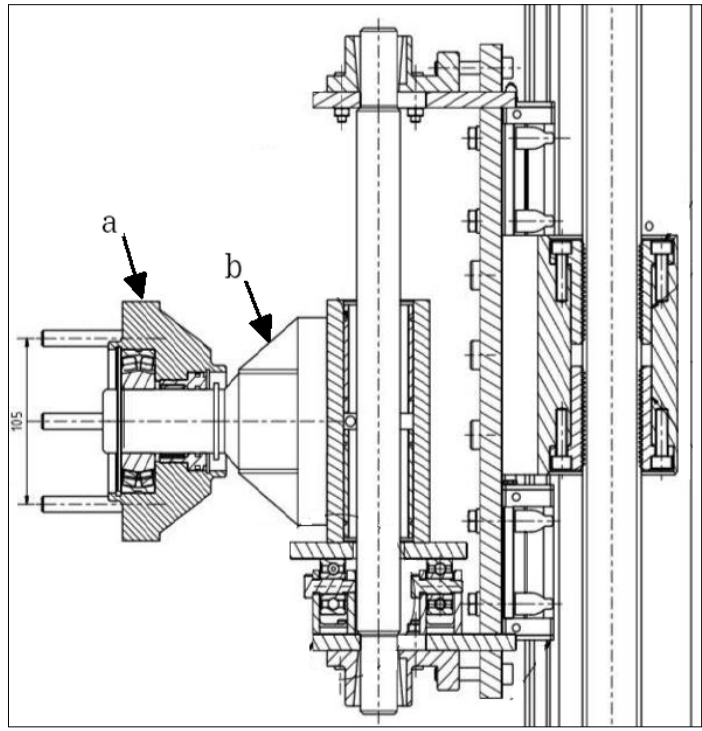

9. ábra. Segédberendezések metszete

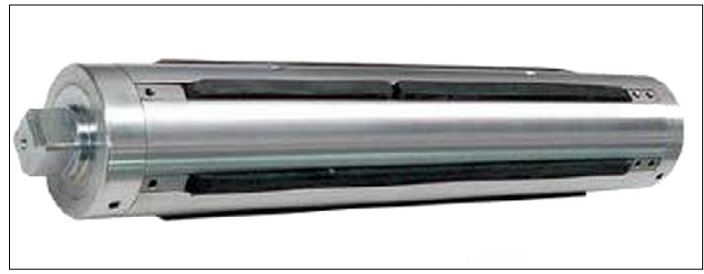

10. ábra. Pneumatikus rögzítőtengely

ható a két, egyedi gyártással készítendő alkatrész, melyek szerkezeti kialakítását a következőkben mutatom be. A tekercseket rögzítő tengely legygyakrabban a papír, illetve a szövetgyártásban alkalmazott (10. ábra). Megnevezése: pneumatikus megfogótengely. Müködési elve: a tengelyen található gumipofák nyomás hatására szorítóerőt fejtenek ki a ráhelyezett elemekre, jelen esetben a tekercsek dobjára, amelyet pozicionálni és rögzíteni szükséges.

\section{Végeselem-vizsgálatok}

A tekercselőegység tervének elkészítését követően 3 dimenziós modellek segítségével megvalósíthatóvá vált a végelem-analízis. A Solidworks szoftver [3] végeselem-moduljának felhasználásával elvégeztem a fontosabb szerkezeti elemek szilárdsági ellenőrzését.

Kiemelt feladatnak tekintettem a legnagyobb terheléseknek kitett szerkezeti egységek ellenőrzését, a tekercs súlyát hordó elemek vizsgálatát. $\mathrm{Az}$ ellenőrzést minden részegységre végrehajtottam helyettesítő modellek segítségével.

\subsection{A csatlakozótárcsa vizsgálata}

Az első egyedileg készített alkatrész a tekercs tengelyét tartó csatlakozótárcsa. A tárcsára (9. ábra „a” jelű alkatrész) a tekercs súlyából adódó erők és nyomatékok hatnak.

Hat darab tőcsavar rögzíti egymáshoz a tárcsát, illetve a tengelyt. Ezen a hat csavaron adódik át a terhelés. A szimulációt bemutató 11. ábrán jól látható, hogy a csavarokban ébrednek a legnagyobb feszültségek. A csatlakozótárcsa igénybevételeit az 1. táblázatban tüntettük fel. A méretezés helyességét igazolta, hogy a feszültségek és deformációk minden esetben az anyagra megengedett értékeknél kisebbek voltak.

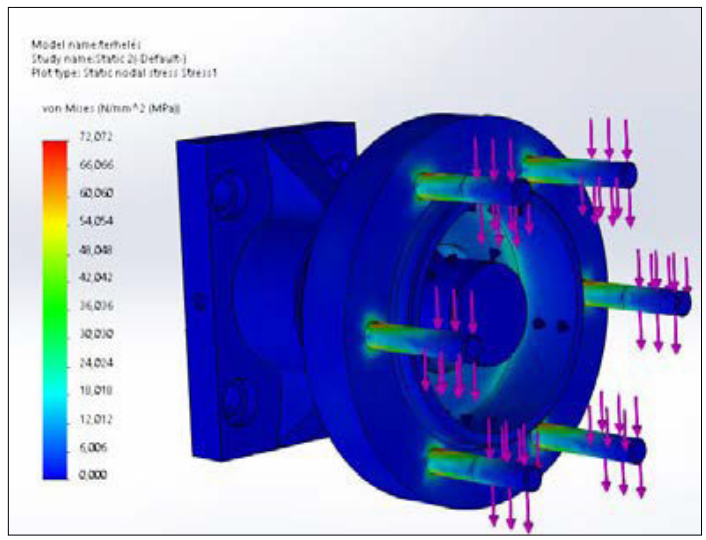

11. ábra. Csatlakozótárcsa VEM-vizsgálata

1. táblázat. Csatlakozótárcsa igénybevételei

\begin{tabular}{|l|c|}
\hline Igénybevétel típusa & Maximum \\
\hline Ekvivalens feszültség: $\sigma_{e q}$ & $72,1 \mathrm{MPa}$ \\
\hline Elmozdulás, kihajlás & $0,19 \mathrm{~mm}$ \\
\hline
\end{tabular}

\subsection{Csatlakozó tengelycsonk}

A csatlakozótárcsa szintén egyedi gyártással készülő szerkezeti elem (9. ábra „b” jelű alkatrész). Ezen helyezkedik el az előző pontban bemutatott csatlakozótárcsa. A tengelycsonk felülete köszörült a csapágyak megfelelő illeszkedése miatt. A tengelycsonk négy csavarral csatlakozik a lineáris csapágyházhoz.

A 12. ábrán megfigyelhető, hogy a legnagyobb feszültség a váll felülete mögött, a kúpos felületen ébred. A váll a csapágy megtámasztása érdekében szükséges. A legnagyobb ébredő feszültség 13,5 MPa, amely nem haladja meg az anyagra megengedett maximális értéket. Az anyagra jellemző megengedett $\sigma_{\text {red }}=512 \mathrm{MPa}$. 


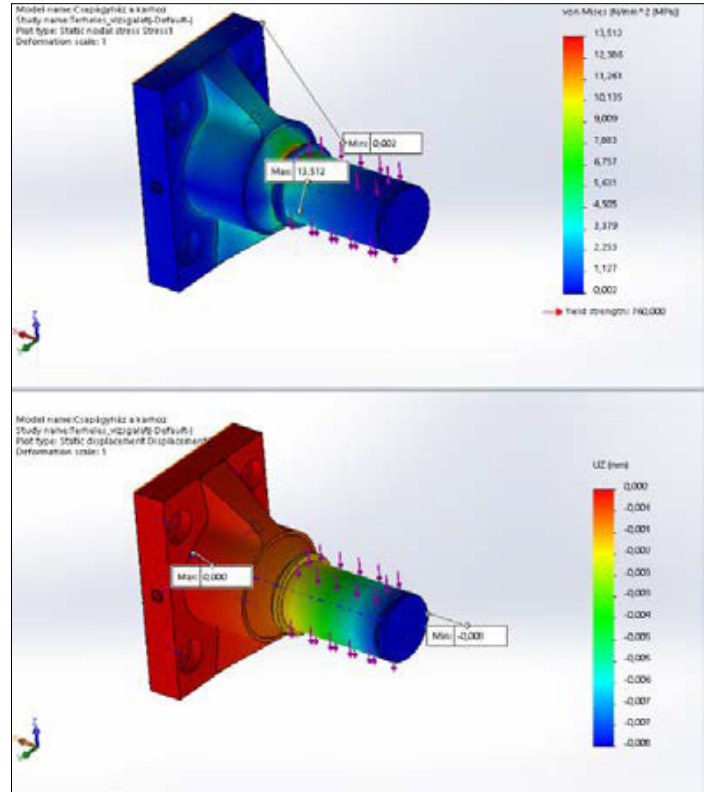

12. ábra. Csatlakozó tengelycsonk VEM-vizsgálat

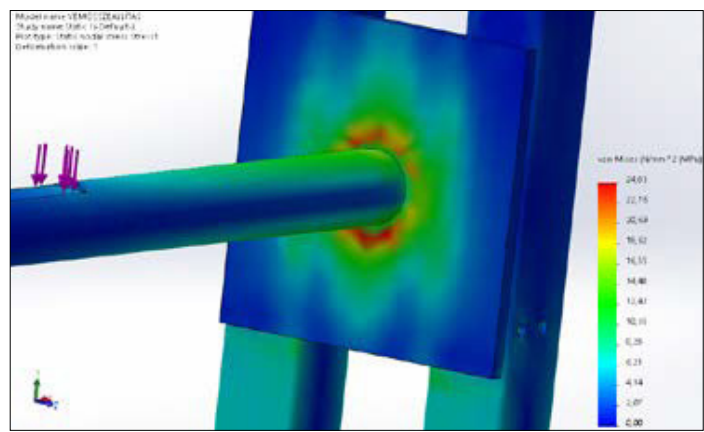

13. ábra. A tartólapban ébredő feszültségek

\subsection{A tartószerkezet vizsgálata VEM-mód- szerrel}

A tartószerkezetekre is elvégeztem az ellenőrző vizsgálatot. Az alkatrészek jelentős száma és bonyolultsága miatt indokolt volt helyettesítő modellek használata. A vizsgálati eredmények és a feszültséggyűjtő helyek a 13. és 14. ábrán lathatók. Az ébredő feszültségek egyik helyen sem haladják meg a megengedett értéket.

\section{Technológiai tervek készítése az egye- di alkatrészek gyártásához}

A szövettekercselő egység legnagyobb terhelésnek kitett alkatrészei bonyolultságuk, illetve kialakításuk miatt 5 tengelyes CNC-vezérlésű szerszámgépen gyárthatók le.

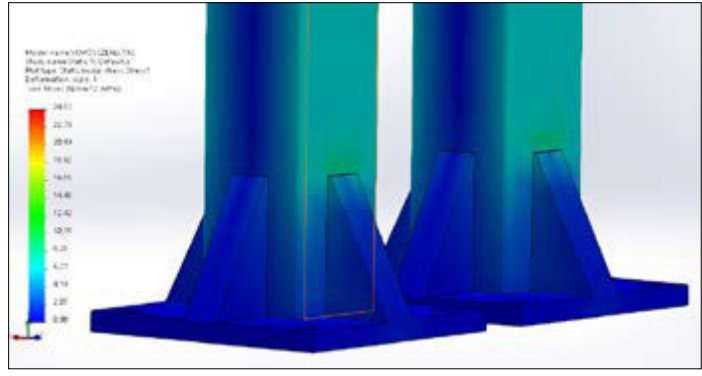

14. ábra. A talpakban ébredő feszültségek

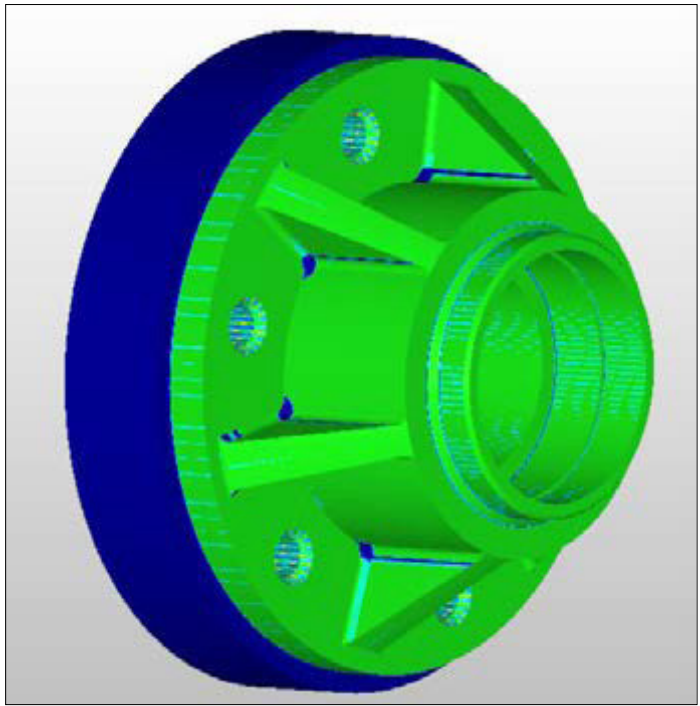

15. ábra. Csatlakozótárcsa megmunkált felületei

Ehhez EdgeCAM [4] szoftverrel elkészítettem az alkatrészek CNC-megmunkálási programját és szimulációt is készítettem a megmunkáláshoz. A 15. ábrán látható a szimuláció végén kialakult felület, zöld színnel jelöltem a megmunkált felületeket.

Látható, hogy a csatlakozótárcsa a megmunkálás befejeztével még rendelkezik (kékkel jelölt) nem pontosan megmunkált, ráhagyást tartalmazó felületekkel. A pontos, rajz szerinti megmunkáláshoz a merevítő bordák közelében igen kis méretű szerszámot kellene alkalmazni, amely jelentősen növelné a megmunkálási időket. A jelölt felületeken maradó ráhagyás nem befolyásolja a megfelelő müködést.

A csatlakozó tengelycsonk (16. ábra) megmunkálása körülményesebb és nagyobb szerszámozottságot igényel, egy felfogásból nem készíthető el. A második felfogást követő megmunkálás után a tengelycsonk hátfelülete egyetlen marad, ezért külön megmunkálást igényel. 


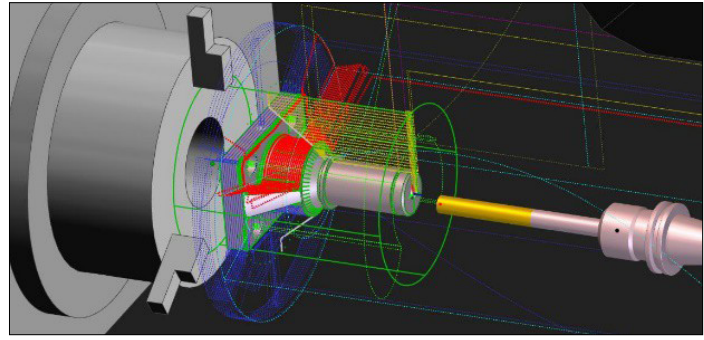

16. ábra. Tengelycsonk felfogási vázlata

\section{Fúrótárcsás készülék}

A csatlakozó tárcsa gyártásához nem indokolt a készülék használata, ha CNC-vezérlésű szerszámgéppel történik a gyártás. Amennyiben azonban a müködő felületek előállítása hagyományos szerszámgépen történik, indokolt a megmunkálás pontosságát növelő készülék használata. Ezért, sorozatgyártást feltételezve, megterveztem a gyártás megfelelő pontosságát biztosító fúrókészüléket (17. ábra).

A készülék használatával a megmunkálás automatizálttá válik. A furatok osztását léptetőmotor hajtja végre, a pontos méretű és helyzetű furatok elkészítését a fúrólapba rögzített fúróperselyek biztosítják. A furatmegmunkálás során egy pneumatikus megfogó egység rögzíti az alkatrészt elmozdulás ellen.

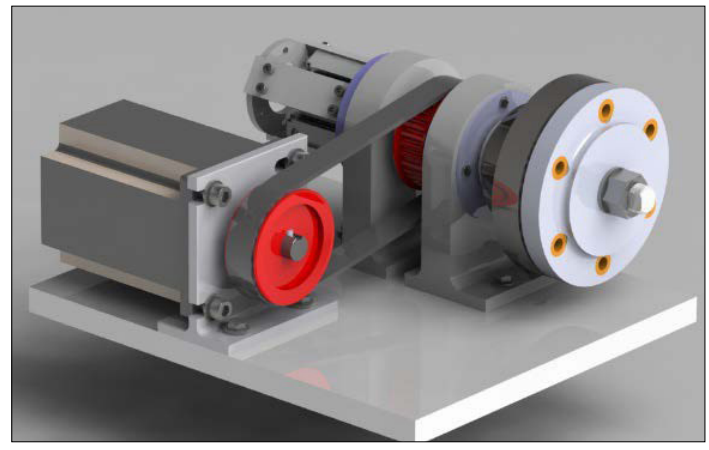

17. ábra. Automata fúrótárcsás készülék

\section{9. Összefoglalás}

A dolgozatban bemutattam a szövettekercselő egység tervezésének, ellenőrzésének folyamatát, a berendezés fontosabb elemeinek gyártástechnológiáját. A fejlesztés gyakorlati megvalósításáról, a gyártási költségek pontos meghatározását követően, az üzem vezetősége fog dönteni.

\section{Szakirodalmi hivatkozások}

[1]Bartha Z.: Gumiipari kézikönyv. Taurus-Omikk, Budapest, 1985.

[2] Herczeg A.: Szerkesztési atlasz. Műszaki Könyvkiadó, Budapest, 1980.

[3] www.solidworks.com

[4] www.egdecam.com 